\author{
Military Technical College \\ Kobry El-Kobbah, \\ Cairo, Egypt
}

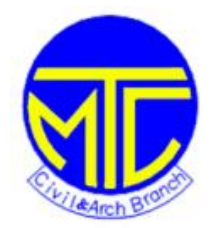
$9^{\text {th }}$ International Conference on Civil and Architecture Engineering ICCAE-9-2012

\title{
Hybrid microclimatic village planning methodology for sustainable desert settlements; revisiting Mid -Sinai as a case study Hosam Rizk** and Mohammad Fahmy*
}

\begin{abstract}
This paper presents a hybrid sustainable design methodology for desert settlement development on a microclimate thermal impact basis. Sustainable development had broadcasting and cumulative interdisciplinary thoughts through time. Main approaches started in the early 1980 s by the UN to define the future strategies for resources as a moral and physical commitment towards next generations. In a $4 \%$ inhabited hot arid country like Egypt, there should be a n ew development model that stresses on the effect of climate conditions within sustainable design process. As a development type of desert settlements, the concept of country desert villages is viable as it lies between both urban settled communities in north and south Sinai and the unsettled population in med-Sinai. Such settlement/village planning ideas has succeeded in Israel for example through the combined fields of applied research; desert physical planning and passive solar architecture, prefabric ation and low-cost construction methods and materials, building physics and climatology, desert agriculture and renewable energy systems. Despite the early rise for the sustainable development age in the 1980s, till now the two lines of sustainable physical planning and the radical Egyptian development discipline based on the socialist central housing strategy didn't meet in a hot country like Egypt. This is due to the Just to Accommodate People methodology using only the Traditional Neighbourhood Development fabric forms without considering the conditions of the eight climatic classifications and different social habits of people in Egypt. This work revisits the regional development concepts for Sinai, to select pilot development spots around existing communities in Med-Sinai after which zero energy low-cost housing development can be applied on a microclimate basis using a hybrid passive design methodology. The suggested Desert Village Planning focuses on generating a character for patterns in different regions by accommodating people in socially acceptable houses via public participation, economic activity support for village jobs, maintaining acceptable services with outdoor social places, diverse and compact fabric form, prefabrication with low-cost materials and construction, and low or zero energy community. On the other hand, numerical impact assessment for village forms using building simulation tools solves complex aspects of these intersected fields in different locations on a microclimatic basis .
\end{abstract}

\section{Keywords;}

Sustainable development, microclimate, desert settlements.

\footnotetext{
* Department of Architecture, Military Technical Collage

${ }^{* *}$ Co-operative Housing Authority, Ministry of Housing, Urban development and Urban Communities
} 


\section{Introduction}

The expression sustainability refers to the balance between consuming natural resources and the capability of environment to replenish [1-4]. It has been issued as a moral duty for the future generations in 1987 by Bruntland [4]. Consequently, urban sustainability definition is a composition of its goal and concept. Concept refe rs to the needs of users whereas goal refers to the development scale at which needs are designed and resources are either consumed or replenished; i.e. the community can sustain itself. From this standing point, the basic triangle of sustainable developm ent concerns how to maintain urban communities performing socially, environmentally and economically balanced via three motors; university, industry and government [5]. Same authors presented a development for this triple helix m otors model to cover the weak connection between principles and applications since sustainable development concepts are still far from reality. Triple helix model had three other motors; knowledge, learning and market which promote close connection betwee $n$ stakeholders but needs more time. This might not be available in an urban degraded environment and overwhelmed politically transient country like Egypt after $25^{\text {th }}$ of January 2011 revolution considering the wide ranges of related studies /surveys/public participation $[6,7]$ prior to the design stage particularly through radically oriented urban planning system. Urban planning has been always the cumulative protocol of constructing communities. At a time of climate change, lack of resources and such radical Egyptian protocol needs revision to cope with people's welfare ambitious. Globally, population is estimated to reach 7 billions, $60 \%$ of them will be living in urban areas and 9 billions by $205070 \%$ of them in urban areas [8]. In Egypt, the population exceeded 80 millions in 2008 [9] occupying 4\% of the Egyptian lands which means to retake the control of population density; not only informal urban areas has to be regenerated $[10,11]$ but also deserts cannot be denied. Desert settlements are not comparable with urban development due to harsh climate and scarcity of water and energy. Consequently, a site of no foreground nor underground water source shouldn't be considered for settlement development even if a renewable energy source is guaranteed which means a huge regional approach has to take place to help appropriate site selection. In this concern, the physical landscape planning of settlement patterns has to follow passive design discipline to provide shelter from harsh conditions and to save energy $[12,13]$ along with providing economic base as well as social acceptable housing typologies with social mobility featu re induced by recreational places which in turn deliver sustainable forms [14-16]. Exampling fabric physical planning, Fahmy \& Sharples [17] discussed the cluster as a mid-latitude fabric unit which hybridizes the concepts of solar sheltering while allowing wind access and on the other hand conclude urban diversity [18]. This could be suburban or rural areas development, but cannot be desert as the cluster closure ratio was a bit large to prevent sand storms. More studies are then needed towards avoiding the canopy layer plum [19] from entering clusters/courtyards of residential groups. Sustainable physical design of fabric has been translated through three approaches of research; revivalist which focuses on passive design principles in vernacular architecture, the progressive gathers technology and traditional neighbourhood development, and the hybrid approach that gathers all previous aspects in terms of urban regeneration for existing patterns but thi s applies for urban areas rather than desert ones [20-22]. In urban areas, development depends on the state energy and water networks whereas in desert settlements these resources have to be guaranteed separately. In addition, untraditional construction methods have to be considered. 
On the other hand, pre-design sustainability studie s needs political will to support providing affordable housing and jobs by settlement economy which in turn needs special economic definition for each site market as a matter of settlement existence $[23,24]$. Market is the civic institution which is capable of driving massive changes in environment and people opportunities on a hand and at a speed tha thangs the regulatory powers on both national and international scales on the other hand. Human quality of life and needs are strongly linked to the performance of that economy. In the twentieth century, tighter regulation of markets have been argued by environmentalists, but complications of how to engage the power of markets to secure environmental services and biological diversity have been shown.

From this standing point, this work presents new thoughts of designing the three main elements of the urban built environment; fabric, network and vegetation and focusing on sustainability measures like thermal comfort, green house gases emissions and zero energy supply as microclimatic derivatives for sustainable settlement in Sinai as a case study. This is crucial if we are to address thermal comfort, low -carbon economy and zero energy demand, which are assessment parameters for both industrialised and non-industrialised countries.

\section{Case study}

Sinai is the eastern part of Egypt across the Swiss Canal, bet ween ......N and ....E. Sinai now has about 530 thousands population spread over about 60 thousands $\mathrm{km}^{2}$ [9]. Its weather is classified as 4A by ASHRAE standards 90.1 which is Humid Subtropical/Humid Continental with warm summer and cold winter derived algorithmically from the source weather data measurements of about 36 years since 1969 [25]. Sinai has been made five regional development models based on three concepts of civil and military academic research bodies. These concepts were horizontal east-west development ways by Cairo university 1982 and New Urban Development Communities Authority 1987, south-north development ways models by Nasser Higher Military Academy 1987 and Egyptian Army Engineering Institute 1988 and the grid of focal development points' model by both the Ministry of Housing, development and New Communities as well as the Military Technical Collage $[26,27]$. It can be argued that both later studies consider hybrid regional development model compared with the fou $\mathrm{r}$ formerly mentioned models, fig. 1/ a, b. Hybrid development focuses on the development focal cities, towns and centres in addition to ways rather than development ways only. This means that development initiates over about 16 points which is classified as main development poles, secondary development poles and service centres. These poles and centres are classified on economic basis as industrial, irrigated agriculture, country and tourism and radiates towards each other through a regional vehicle networ k. From this standing point, it can be realized that regional development model is physically composed of multi local development models of neighbourhood/village on a microclimatic basis that transfers local sustainable development of a site regionally to consider climate for energy saving purposes in such desert settlements [28], fig. 2. On the other hand, the later study suggests a start with local development concept which copes as a pattern unit with the service centre of Rizk 1992 and Dames \& Moore 1985 but all haven't discussed the design methodology for such sustainable desert village development regardless its economic activity and whether it has a new economic activity as a new development or stands alone near to an already existing city or town as it should [29]. Dames and Moore 1985 argued that middle Sinai high lands as the minor population density part needs development as country due to its 
agriculture tendency. Therefore, from a physical planning point of view, considering renewable energy planet land use is crucial to provide zero energy villages, help sea water desalination (for coastal develop ments), get underground well water and supports low-cost socially acceptable housing typology by energy cost savings. After all, in Sinai and Egypt, such desert village development design methodology needs continuous research as well as research groups th at combines and covers topics of desert environmental physical planning, prefabrication and low -cost construction methods and materials, building physics and climatology, desert agriculture and renewable energy systems. In Israel, one can find these appro aches having great success owed to Beer Sheva' and Sede Boqer research centres in the Negev desert and can be realized from the number of research publications, focusing on these combined research [30-36].

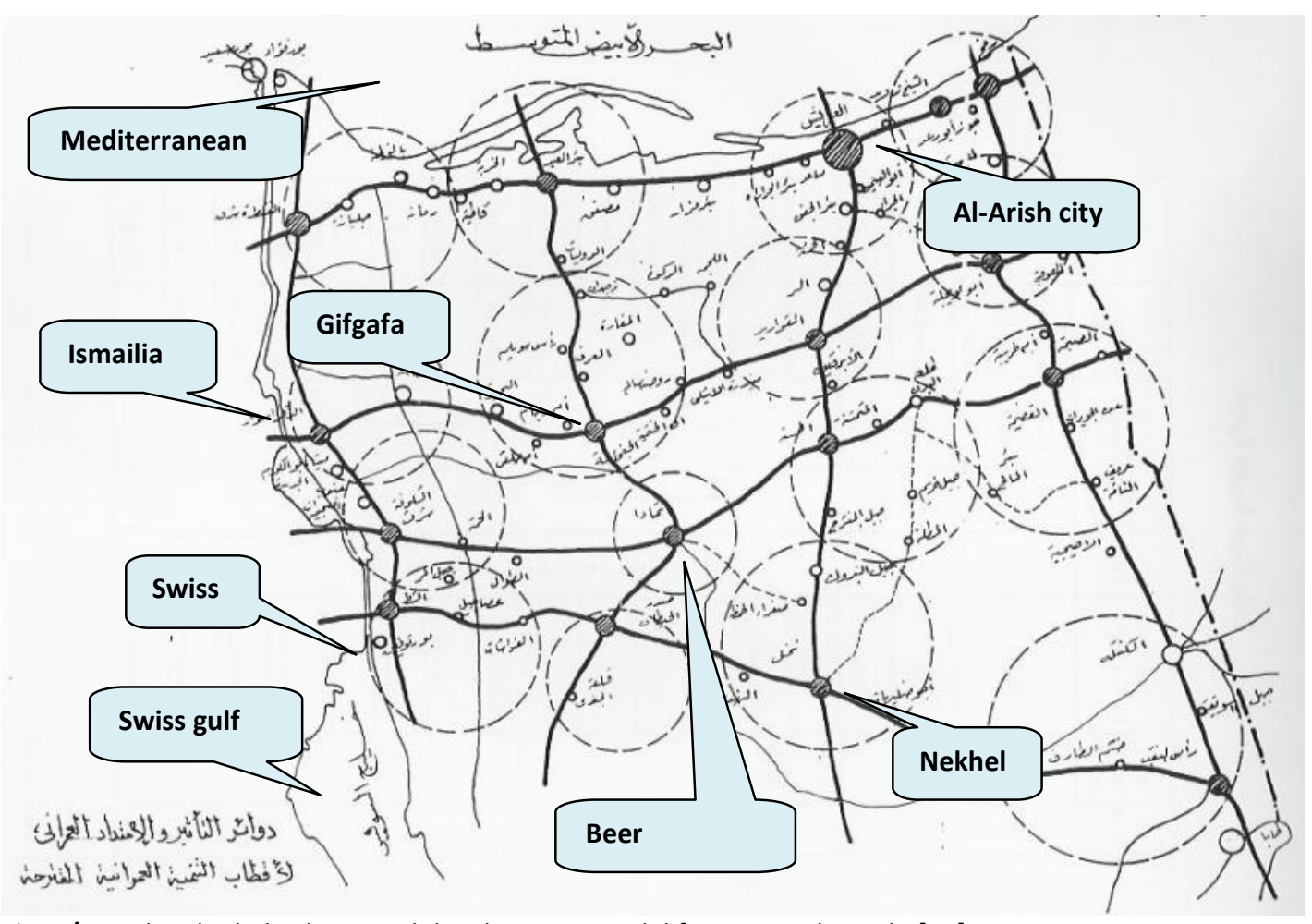

Fig. 1/a: Rizk Polar hybrid regional development model for Sinai. Adopted, [27]. 


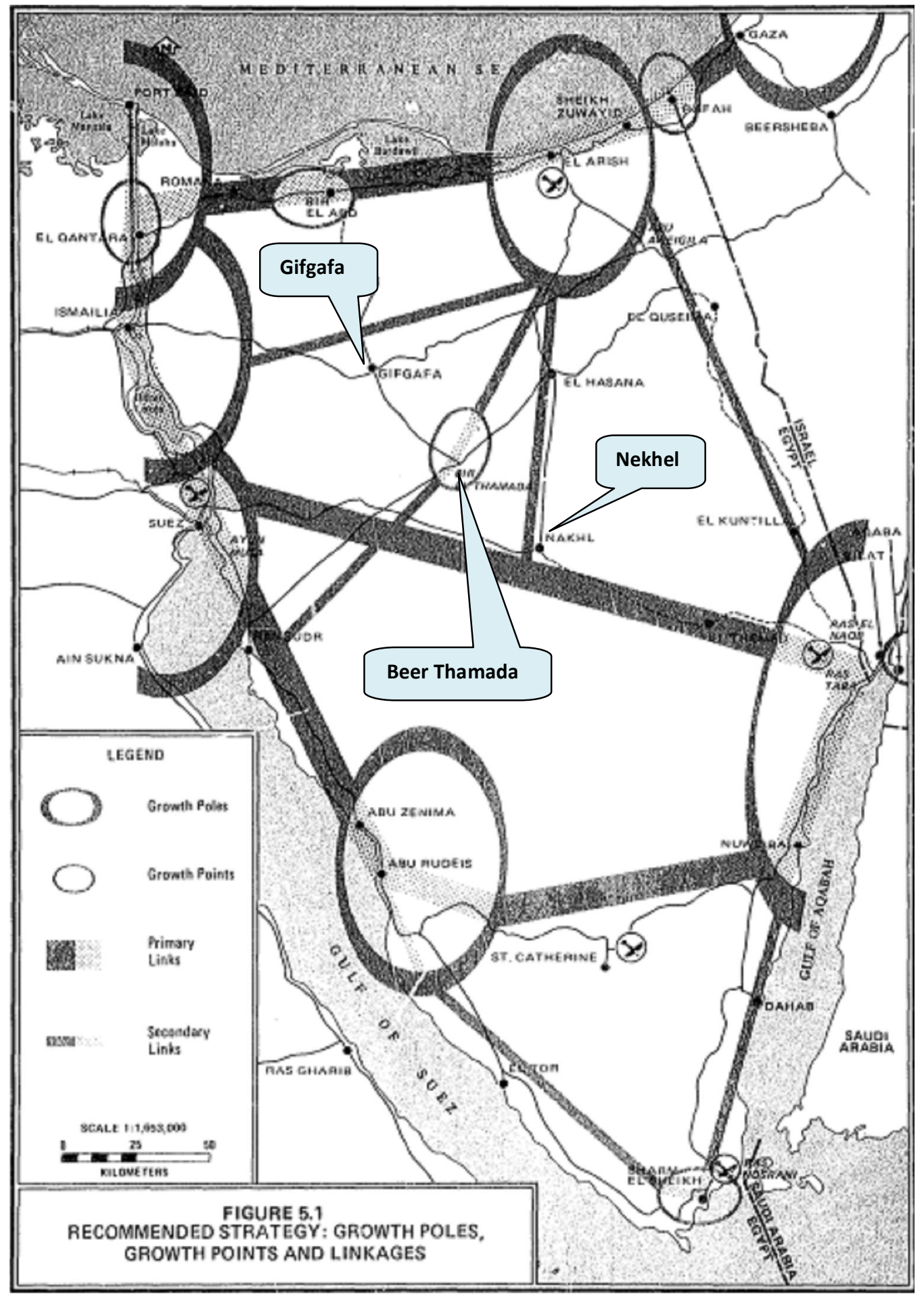

Fig. 1/b: Dames and Moore hybrid regional development model for Sinai. Adopted, [26].

\section{Methodology}

\subsection{Desert Village Development}


Desert settlement development methodology is a combination of resources and jobs provision mechanism, desert village physical planning and environmental management methodologies. This can be cumulated as following:

1- Resources and jobs provision methodology:

a. Water from wells or desalination using renewable energy.

b. Renewable energy planets for electricity and water provision.

c. BOT private and governmental agriculture and agricultural industrial projects.

d. Zero interest lawns for small industries; palm trees indust ry and rugs.

2- Passive physical planning for village form:

a. Compactness.

b. Diversity.

c. Country housing.

d. Clustered fabric.

e. Thermal insulation for roofs and walls.

f. Cool surfaces and higher Albedo values.

g. Indoor - outdoor low energy lighting devices.

h. Construction prefabrication.

i. Low-cost construction materials.

j. Desert adaptive vegetation.

k. Civic services and outdoor places on a mixed use basis rather than on a traditional neighbourhood/village basis.

1. Transportation alternatives, stations and connection with region al and local networks.

3- Environmental management:

a. Water recycling and management systems.

b. Domestic waste and sewage recycling units per neighbourhood/village.

c. Village municipal skeleton.

d. Environmental impact assessment reports for present day and c limate change scenarios.

\subsection{Physical planning statistics}

Mid-Sinai has been assigned on an economic activity for development as country side in the development model of Dames and Moore 1985 and for polar development by Rizk 1992. In this section, a land use for a zero energy village of 6000 (6 people/family) people is suggested near Beer Thamada or Gifgafa town, fig. 3, which is proposed to develop as service centre based on the principle irrigated candidate areas for agriculture in both mentioned region al development models. Each village can be having a farm of 30 thousands Feddans for agriculture. 


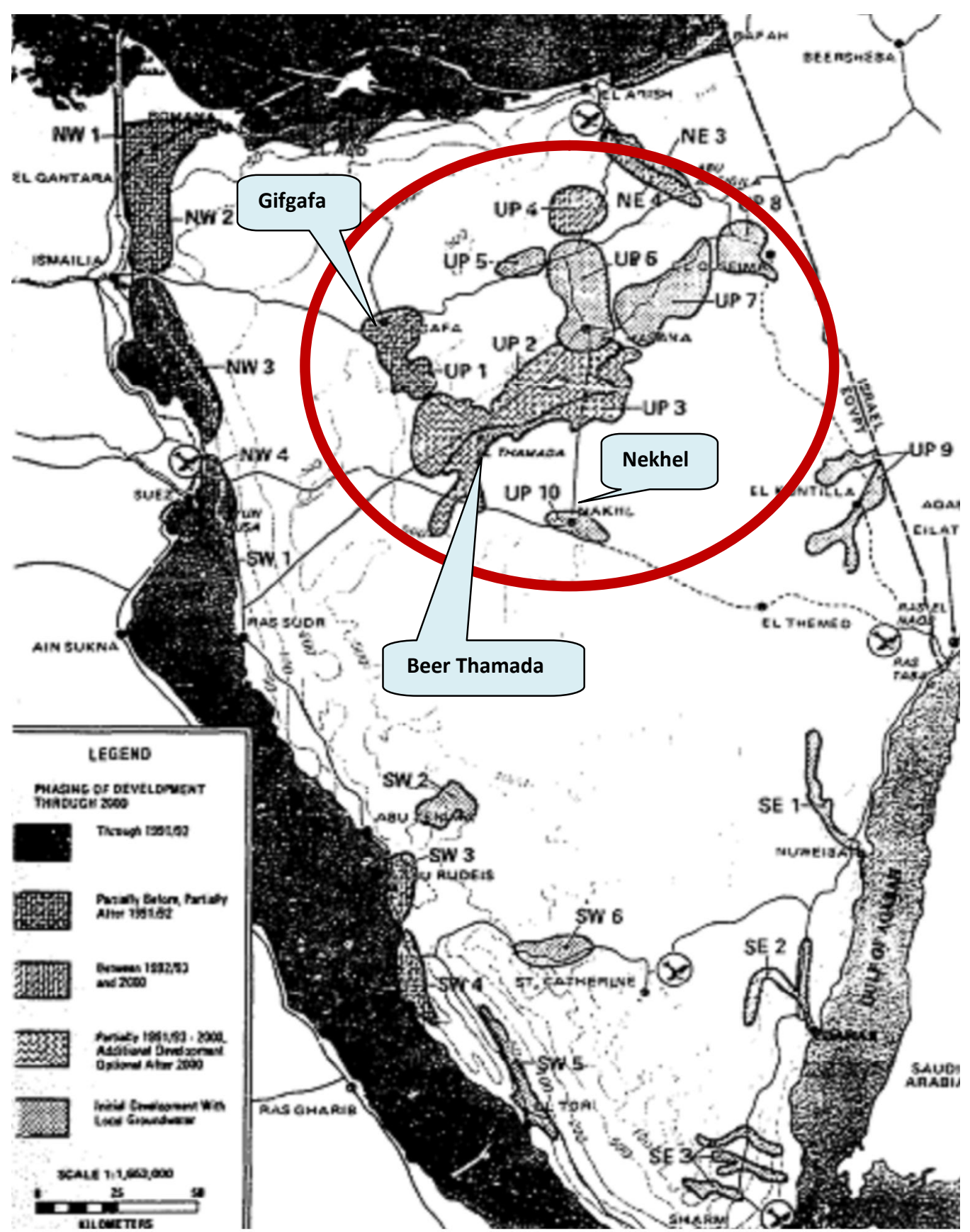

Sinai housing depends on the simplicity of construction and form. Frankly speaking, mid-Sinai families still tend to feed sheep grass through trav elling in the rain season, therefore they prefer some times to build small rooms spread over the area of their interest to store subsistence for them to use when passing near by searching grass for their sheep. This is why it is difficult settling Sinai p eople than stimulating canal citizens to come few tens of kilometres from their original cities. Moreover, it is beneficial to construct drinking nodes around the area proposed for However, to sort this point out a much simple court yarded ground floor of $80 \mathrm{~m}^{2}$ for housing typology is suggested with low-cost of $700 \mathrm{LE} / \mathrm{m}^{2} 20$ years paying system and land, energy and water for free. In addition, a prefabrication system for this so called semi -settled 
housing is proposed using GRC construction to achieve this l ow-cost as well as erection in short time (3 days), an example of GRC housing is illustrated in fig . 4/a, b [37]. Different designs of this housing unit can be then offered to questionnaire participants in the near cities to Beer Thamada and Gefgafa so that they can have an idea bout the proposed project and select the one can be executed. Eventually, settler has to pay about 2500LE/year only for housing but committed to follows the economic plan of the government. Settler commitments are to plant strategic crops like wheat, corn and biological fuel crops whereas government commitments are to build renewable planets for desalination of well water and domestic electricity as mentioned in the strategic plan for Egypt along with other desert development techniques [38]. With regard to renewable planet land use, the 6000 people electricity demand for cultivation, domestic and outdoor uses of the village are about $5 \mathrm{MW}$ which needs about 10Feddans for PV planet or about 3Feddans for solar thermal planet and demand can be reduced if an individual wind turbine of $3 \mathrm{kw}$ is constructed for each housing unit, fig. 5/a, b, c, d, e. A proposed factory for PV cells is now in the tender stage, it would then cost about 2000LE/kw. A wind turbine has been designed and tested as a research product in the Military Technical Collage and the Egyptian Army Engineering Authority. These renewable systems can be applied after passive design to achieve zero energy housin g [38]. The strategic plan for Egypt in addition to Dames and Moore study indicates the high d evelopment tendency of mid-Sinai provided that political support and continuous development potential are exist fig. 6 .
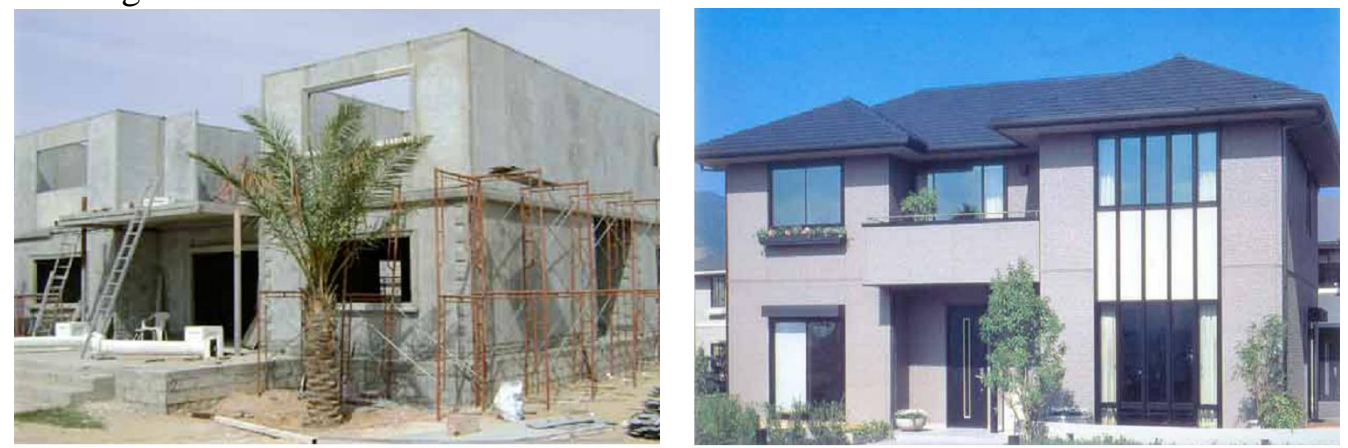

Fig. 4/a, b: 2 floor GRC housing unit example, Angloa 2009, adopted [37]. 

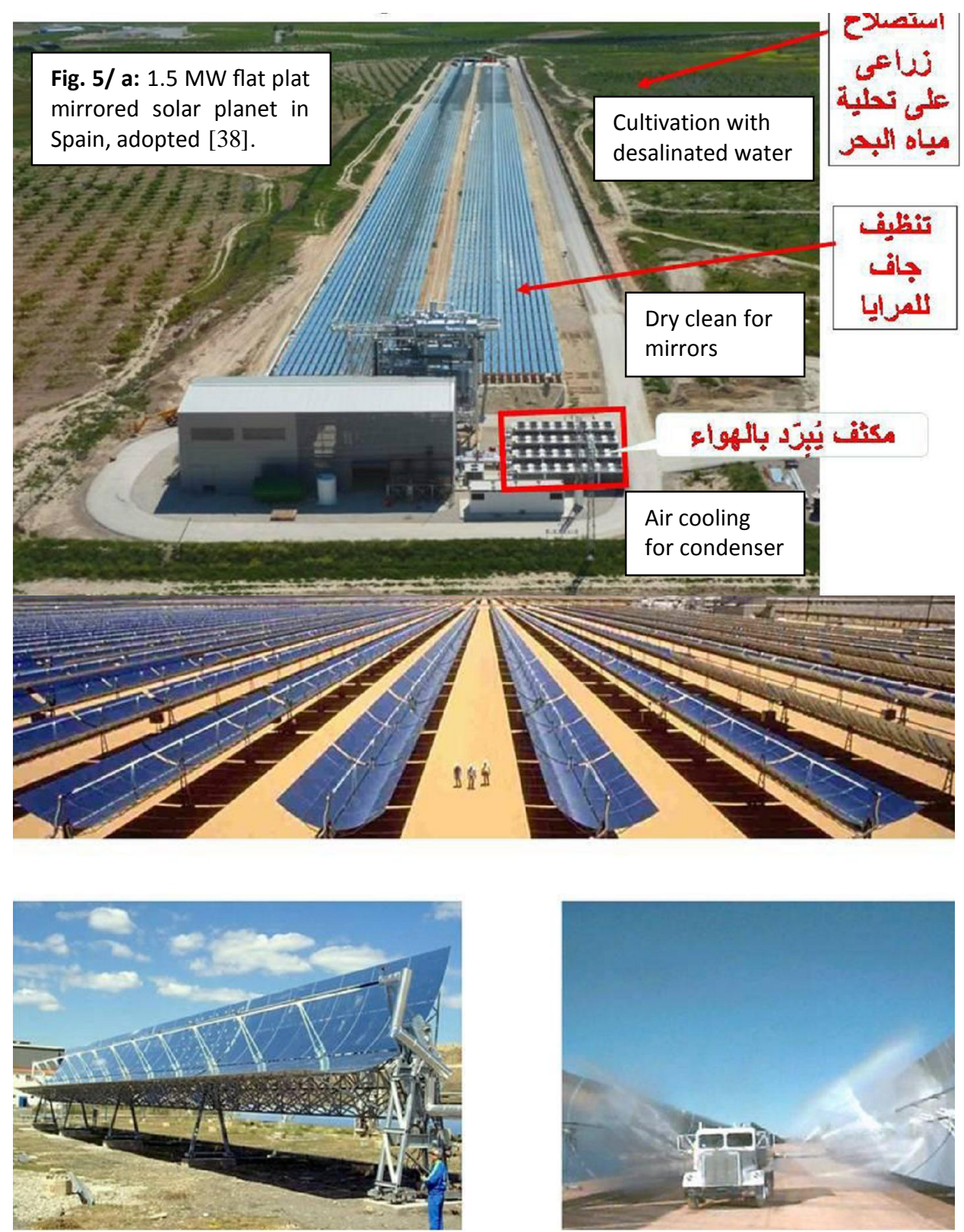

Fig. 5/b, c, d: 354 MW solar thermal plant since 1985 in California, adopted [39].

Fig. 5/d: Individual 3kw wind turbine for single family housing unit, adopted . 

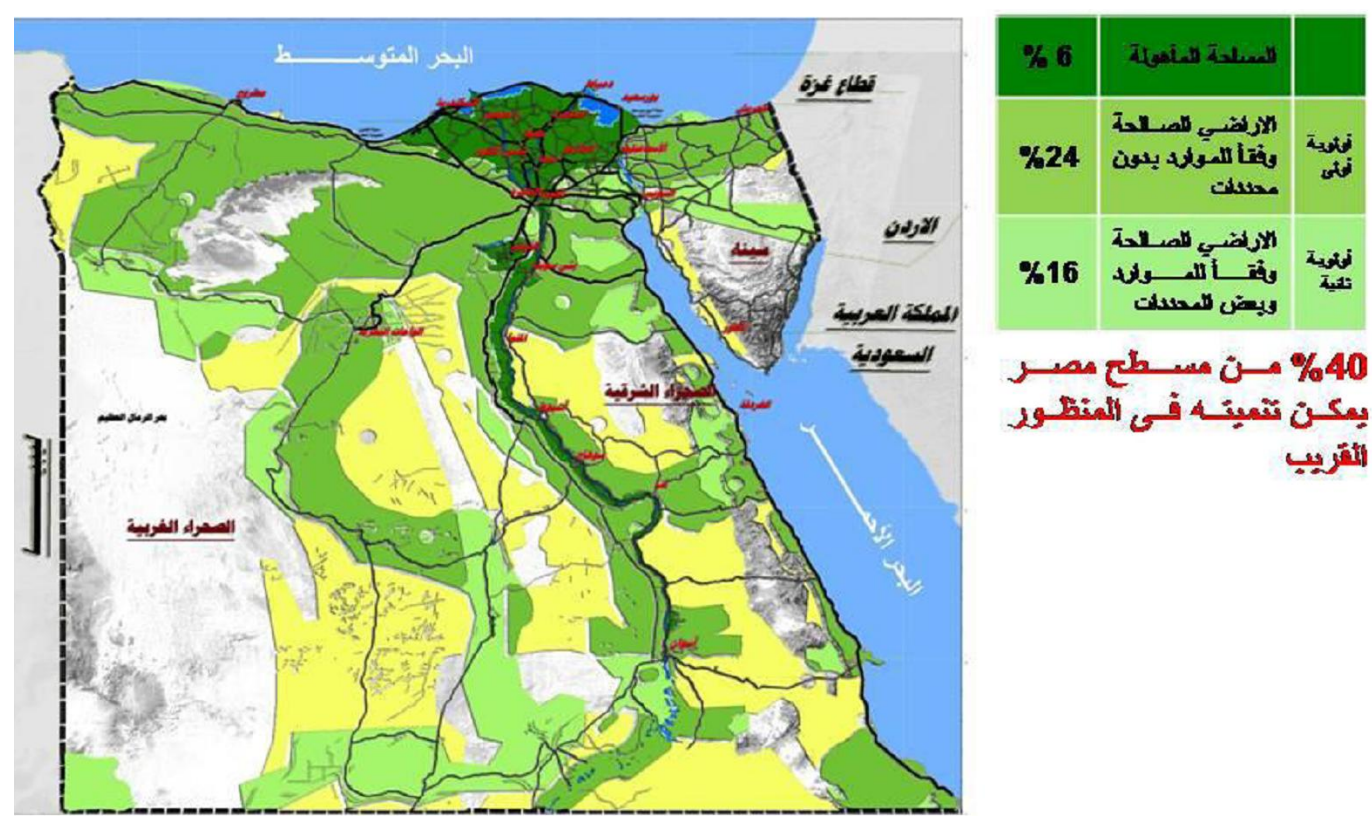

Fig. 6: expected priorities for Egypt land development depending resources, distance from existing inhabited areas and on security aspects; dark green is th e inhabited area, medium green is candidate for first priority development, light green for second priority and yellow is third. The plan expects that about $\mathbf{4 0 \%}$ of Egypt's land can be developed in less than 100 years. Adopted, [39].

\section{Conclusion}

This paper presented a desert village development methodology based on a combination of sustainable strategies and argues that this village would be a planning unit for the mid-Sinai zone which is proposed to be agricultural economy place. Eventually, the study selects two sites for pilot villages to be constructed near the existing patterns of Gifgafa and Beer Thamada. The physical planning for this village stands on two main pillars; low-cost prefabricated co-operative housing and renewable energy for bringing well water for drinking and irrigation. The study supports the feasibility of const ructing such pilot country villages as energy, water and housing costs are almost at no cost compared with traditional methods provided that political support exists as well as continuous development potential.

\section{References}

1. Hoballah, A., Sustainable development in the Mediterranean region. Natural Resources Forum, 2006. 30(2): p. 157-167.

2. Pezzoli, K., Sustainable Development Literature: A

TransdisciplinaryBibliography. Journal of Environmental Planning and Management, 1997b. 40(5): p. 575 - 602.

3. Pezzoli, K., Sustainable Development: A Transdisciplinary Overview of the Literature. Journal of Environmental Planning and Management, 1997a. 40(5): p. 549 - 574.

4. Bruntland, G.H., Global change and our common future. Environment 1989. 31(5): p. 16-20, 40-42.

5. Lombardi, P., et al., An Advanced Triple-Helix Network Model for Smart Cities Performance, in Green and Ecological Technologies for Urban Planning: 
Creating Smart Cities, O.Y. Ercoskun, Editor. 2012, Information Science Reference: Washington.

6. Shirvani, H., The Urban Design Process. 1985 NewYork: Van Nostrand Reinhold Company.

7. Moughtin, C., Cuesta, R., Sarris, C., Signoretta, P., Urban Design: Method and Technologies. 2000, London: Architectural Press.

8. IPCC1, Climate Change 2007: Synthesis Report, fourth assessment report of climate change. Online at:

http://www.ipcc.ch/publications_and_data/publications_and_data_reports.shtml. 2011: Valencia, Spain.

9. CAPMAS, Final Report of Population Statistics for Egypt 2006. 2008, Central Agency for Public Mobilisation and Statistics: Cairo.

10. Kipper, R. and M. Fischer, eds. Cairo's Informal Areas. Between Urban Challenges and Hidden Potentials. Facts. Voices. Visions. Cairo, June 2009 ed. 2009, GTZ Egypt, Participatory Development Programme in Urban Areas (PDP). Deutsche Gesellschaft für Technische Zusammenarbeit (GTZ). Cairo.

11. Sutton, K. and W. Fahmi, Cairo's urban growth and strate gic master plans in the light of Egypt's 1996 population census results. Cities, 2001. 18(3): p. 135-149.

12. Shashua-Bar, L. and M.E. Hoffman, Quantitative evaluation of passive cooling of the UCL microclimate in hot regions in summer, case study: urban streets and courtyards with trees. Building and Environment 2004. 39(9): p. 1087 1099.

13. Shashua-Bar, L., D. Pearlmutter, and E. Erell, The cooling efficiency of urban landscape strategies in a hot dry climate. Landscape and urban planning, 2009. 92(3-4): p. 179-186.

14. Jabareen, R., Sustainable Urban Forms: Their Typologies, Models, and Concepts. Journal of Planning Education and Research, 2006. 26(1): p. 38-52.

15. Roy, M., Planning for sustainable urbanisation in fast growing cities: Mitigation and adaptation issues addressed in Dhaka, Bangladesh. Habitat International, 2009. 33(3): p. 276-286.

16. Chorianopoulos, I., et al., Planning, competitiveness and sprawl in the Mediterranean city: The case of Athens. Cities, 2010. 27(4): p. 249-259.

17. Fahmy, M. and S. Sharples, On the development of an urban passive thermal comfort system in Cairo, Egypt. Building and Environment, 2009a. 44(9): p. 19071916.

18. Fahmy, M. and S. Sharples, Once upon a climate: arid urban utopia of passive cooling and the diver sity of sustainable forms, in SUE-MoT2009 Second

International Conference on Whole Life Urban Sustainability and its Assessment. Loughborough University April 22-24. 2009b.

19. Oke, T.R., Street Design and Urban Canopy Layer Climate. Energy and Buildings, 1988. 11(1-3): p. 103-113.

20. El-gendy, K. Sustainable Desert Settlements. Available online at: www.Carboun.org.uk. 2012 [cited 2012 23/2].

21. Fahmy, M., Integration of Solar Energy Applications with the Architec ture Design of Residential Buildings at Hot Arid Zones, in Arabic, in Architecture Department 2001, Military Technical Collage MTC: Cairo.

22. HBRC, Egyptian code for reducing energy consumption in residential buildings. 2008, Egyptian Ministry of Housing, Utilities and Urban Communities; Housing and Building Research Centre.: Cairo. 
23. Golany, G., Editor of; Planning Urban Sites in Arid Zones, the basic considerations. Book, John Wiley \& Sons, New York, 1978.

24. Jacobe, J., The Nature of Economics. 2000, New York: Modern Library.

25. ASHRAE, ASHRAE Hand Book of Fundamentals (SI Edition) . 2005, Atlanta: American Society of Heating, refrigerating, and Air-Conditioning Engineers Inc.

26. Dams and Moore, Sinai Development Study. 1985, Ministry of Housing, Development and New Communities. Development Consulting Committee: Cairo.

27. Rizk, H., Sinai Regional Urban Development Models, in Architecture Engineering Department. 1992, Military Technical Collage: Cairo.

28. Fahmy, M., Interactive urban form design of local climate scale in hot semiarid zone, in School of Architecture. 2010, University of Sheffield: Sheffield.

29. Bastaweesy, M., A.-W. Helmy, and M. Avbdel-Hafiz, Assessment and Improving Sinai and Canal Region Development Strategy until 2017, in ALAZHAR ENGINEERING NINTH INTERNATIONAL CONFERENCE, April 12 14, 2007. 2007: Cairo.

30. Givoni, B., Climate consideration in urban and building design . . 1998, New York: Van Nostrand Reinhold.

31. Givoni, B., Cooled soil as a cooling source for buildings. Solar Energy Science and Engineering, 2007. 81(3): p. 316-328.

32. Pearlmutter, D., P. Berliner, and E. Shaviv, Physical modeling of pedestrian energy exchange within the urban canopy. Building and Environment, 2006. 41(6): p. 783-795.

33. Pearlmutter, D., P. Berliner, and E. Shaviv, Urban climatology in arid regions: current research in the Negev desert. International Journal of Climatology, 2007. 27(14): p. 1875-1885.

34. Pearlmutter, D., A. Bitan, and P. Berliner, Microclimatic analysis of compact urban canyon in an arid zone. Atmospheric Environment, 1999. 33(24-25): p. 4143 - 4150.

35. Rahamimoff, A., Residential Cluster Based on Climate and Energy Considerations. Energy and Buildings 1984. 7(2): p. 89 - 107.

36. Pearlmutter, D. and I. Meir, Assessing the Climatic Implications of Lightweight Housing in a Peripheral Arid Region. Building and Environment, 1995. 30(3): p. 441-451.

37. Turk, R., GRC Prefabricated Buildings. 2009, Arabian Construction House for Prefabricated Buildings: Cairo.

38. Attia, S., ZERO ENERGY RETROFIT: CASE STUDY OF A CHALET IN AIN SUKHNA, EGYPT, in SOLAR 2010 Conference Proceedings. 2010, American Solar Energy Society: NG, USA.

39. MoHUUC, National Strategic Urban Development PLan, U.P. Authority, Editor. 2011, Ministry of Housing, Urban developemnt and Ultilities: Cairo. 